\title{
XXII. On the Culture of Turnips
}

\section{George Webb Hall Esq.}

To cite this article: George Webb Hall Esq. (1820) XXII. On the Culture of Turnips, Philosophical Magazine Series 1, 56:268, 137-144, DOI: 10.1080/14786442008652381

To link to this article: http://dx.doi.org/10.1080/14786442008652381

曲 Published online: 23 Jul 2009.

Submit your article to this journal

III Article views: 2

Q View related articles $₫$ 
drogen and azote, in the proportions necessary to form ammonia; and probably by an absorption of oxygen from the sulphuric acid.

3. That gelatine may be converted in this way into a species of sugar, sui generis, which does not appear to exist any where naturally.

4. That this sugar combines intimately with nitric acil, without sensibly decomposing it, ever with the assistinnce of heat, and there results a peculiar crystallised acid, to which I have given the name of nitro-saccharine.

5. That wool, and especially fibrine, when treated with sulphuric acid, yields a peculiar white matter, which I have denominated leucine.

6. That this matter, heated with nitric acid, does not sensibly decompose it, and produces a erystallisable nitro-leucic acid.

7. Lastly, That other unerystallisable and sapid substances, analogous to certain vegetable prineiples, are also produced by the action of sulphuric acid on the most insoluble of the animal principles.

\section{On the Culfure of Turnips. By GeORgE WEBB HALI, Esq.*}

Having executed the instructions of the Board of Agriculture, " to condense the whole of the information contained in the several Reports and Communications to the Board on the Cnlture of Turnips," into one general view, that the practice of all the counties in Eugland and Scotland, on this most interesting and important branch of agriculture, might be laid fairly before the public in a compressed form, for the benefit of those to whom all the County Reports and Communications might not be aceessible ; I am tempted to step a little beyond the line of my instructions, in offering to the consideration of the Honourable Board a few observations of my own on the culture of this invaluable root; for which the laborious investigation I have now given the subject, added to my own experience, may render me not altogether unqualified.

If, on the completion of this work, I were to be asked by the Honourable Board, Upon a review of the practice of the whole island, which county do you consider to approseh nearest to maturity in the culture of turnips? I should answer, without hesitation, The county of Middlesex stands unquestionably preeminent to every other in the kingdom in the manner of cultivating turnips; inasmuch as the system there pursued is calculated to produce the best crops nt the least expense, and at the

* From the Communications of the Board of Agriculture.

Vol. 56. No. 26S, Aug, 1820. 
same time promote, nay ensure, the best and clesnest crops of grain in succession.

Let us examine what the very able Reporter of Middlesex, John Middleton, Eso. says on this subject; for it can never be too often printed or read.

"Turnips," he savs, " are undoubterly the basis of the best husbandry, and in every part of this island they will always be a principal crop in the most improvel methods of cultivating loamy sands. They also grow very well on well-drained. blaek peat earth, and on such strong loams as are rich. They support and make fat a very increased quanticy of animal food, and by the dung and urine of fat cattle the land becomes more highly enriched than by any other means. It is an advantage of great importance, that they require such late sowing as to give the farmer an opportunity of reaping two green crops on the same land in one year, both of which may be fed by cattle. A succession of these crops (tares and tumips) may be raised and consumed on dry land till it acquires any desired degree of richness, and will feed more bullocks and sheep than the best grass-land in the kingdom; and, what is of great consequence, it will lue perfectly clean, and fit for every sort of corn during the whole time; but they are crops that are perfectly incompatible with common fields, and for that reason, more than any other, they are so little grown in England. Inclose the common fields, and the tare and turnip husbandry will become general, which will be the most effectual means of loading our shambles with meat, and flling our granaries with corn."

We will now investigate in detail how this system operates, " to produce the best crops at the least expense, and at the same time ensure the best and cleanest crops of grain in succession," as I have above asserted.

The man who, the moment his wheat is cut, and even before it is carried, begins to break up his stubble for. tares, is at no more expense in this operation, than those who give their land a winter-ploughing as a preparation for turnips; and in the spring, while the latter are laboriously and expensively giving their lands three, four, and sometimes five ploughings, as a preparation for turnips, and carting out their dung, his tares are growing on the land intended for turnips; by the consumption of which, by sheep, on the same land, in the month of May, he not only manures his land by their dung and urine, in a much cleaner way than those who haul out their farm-yard and stable dung for their turnips; but he is afterwards enabled, by two ploughings at most, and in sone seasons, and on some lanils, with one, to produce-s fallow, after the consamption of the tares, that for cleanliness and friability shall rival, if not surpass, the fallows of the most 
expensive spring-ploughing withour tares. But even this is only half the benefit which this system confers; for, by obtaining such a redundancy of green food by the latter end of April and all May, the man who follows the tare system is enabled to hain, during May, all his summer pastures for his sheep; which, by having such a provision in tares, he may bite as closely as he pleases, without any reserve, during all March and April, until his sheep go to tares: thus will every man be enabled to enlarge his flock, on this system, to an extent of which no one, who has not tried it, can have any conception; and thus will he be enabled to apply all his farm-yard and stable dung to his Swedes, his potatoes, and; above all, to his pasture land; the ability to do which, from the high condition of the tillage land, by means of green crops and good tilth, not needing the dung, I consider to. be the highest pinnacle on which any man can stand in the art of agriculture.

Again, the man who pursues the tare system, and can apply a large portion of his dung to his pasture land, will have grass on such manured pasture land, by winter haining the same, that shall rival in the month of March any water-meadow in the kingdom in verdure, and surpass it in proof for his couples : this enables him to maintain a larger flock than he could do on any other system, and that will enable him, by folding his lands, when in fallow for wheat after clover, in addition to the consumption of so many green crops on his tillage lands, to bring those to equal fertility, and superior cleanliness, to what he can do by any other method, eyen if he had the manure of the metropolis at command for his tillage lands. In exact proportion, therefore, as every agriculturist approgehes to, or recedes from, the tare sýstem, reported to be pursued in the county of Middlesex, and his ability to apply a great portion of his dung to his pasture lands, I consider him to be in the infancy, youth, or manhood of agriculture; and that those farmers, I will not call them agriculturists, who continue to apply farm-yard or stable dung as a dressing for their wheat fallows, which many do at this day, are only begotten, and not yet born to the light of agriculture.

Having cast so strong a reflection on so numerous a body of men as still continue, in various parts of the kingdom, to apply their farm-yard and stable dung to their wheat fallows, it seems incumbent on me to state the reasons of my dissent from this practice. This I will do in very few words: All dung applied to fallows must generate weeds, and, therefore, it ought universally to be applied on lands of all descriptions immediately preceding a green crep, by which, and the hoe, they may be well subdued, before we trust a crop of grain to a competition with weeds, on the same land. 
Dung applied to wheat fallows, invariably makes the plant winter-proud, long and weak in the straw, and light in the berry, to say nothing of the endless, expensive, and inefficacious practice of weeding wheat; and if these objections are not enough to deter aay man from this absurd practice, who will give himself the trouble to reflect one monent on the subject,-which I do not believe any man ever did who adopted it, - I am certain nothing I can advance will, and I must leave such farmers to tinse and opportunity for improvement; but as the Memoir which I had the honqur to present to the Board last year, on the Culture of Turnips, in mistake for the Condensed View of the practice of all the Counties on this subject, now respectfully submitted to the Board, is in the outset so completely in unison with $\mathrm{Mr}$. Middleton's Report, which I had not then seen, and also contains some observations on manures, in which $l$ have the misfortune to differ with some of the highest authorities in this kingdom, I spljoin such Metmoir to these observations, that the public may decide on its correctness, or demerits.

I eamnot take lease of Mr. Middleton, without offering, a just tribute to his Report of the County of Middlesex; in doing which, I trust I shall be acquitted of all inproper partiality ox fiattery, when. I declare it has been my misfortune never to howe seen, or ever to have heard, of this distinguished Agriculturist, except by his Report above mentioned; but in that $I$ find the most masterly delineations of the practice of the county, the most sound and judicious principles of general agriculture en+ forced, and the true bearing and effect of tenures upon its success, described; -in short, there is no part of rural economy. tonched, but it is illuminated by this very distinguished writer ; and I find in his whole Report, only one subject upon which we materially differ, and that is the system of folding sheep, which he reprobates; but which I consider to be the most certain and perpetual basis of the most perfect agriculture that can possibly be pursued.

Memoir laid before the Board in March 1817.

The introduction and cultivation of turnips in this island, may beconsidered almost as impor tant an æra in the agricultural world, as the Reformation was in the moral; and the right cultivation of this root, may be considered as the pivot on which.successful agriculture on all turnip soils depends.

For, independently of its superseding altogether the necessity. of summer-fallows, on such soils, I consider the annual weight of animal food which it supplies, to have had no inconsiderable slzare in enabling us to victual the increasing population of the united kingdom, and producing at all seasons of the year that 
regular and abundant supply of animal food, which, before their general cultivation, could only be supplied during the summer and autunn months : independently, therefore, of the general amelionation of every crop in succession from turnips, which may be derived from their proper cultivation, this circumstance may be considered as a most valuable consequence of their general adoption.

If, then, to the general rotation, on all turnip soils, of turnips, barley, or oats, clover, one year only, and then wheat, we add an intervening crop of winter tares, on such part, at least, of the shift intended for turnips as is not appropriated for Swedes, I think we shall then have attained the ne plus ultra, in system, of advantageous cultivation upon all the turnip soils of the united kingdom; and after this arrangement, success will mainly depend upon the manner of executing this plan.

Without possessing any prejudice against the drill system of husbandry, or disapproving the use of it in others; I must here confess, I have never considered its adoption as necessary to ensure a more clean and perfect culture than can be maintained on the broadcast system ; and I believe, on most of the experiments which have been made to endeavnur to ascertain the preeninence of the drill to the broadeast husbandry, each party may boast of such alternate success and defeat, as still to leave the question undecided; and therefore, pernitting every man to pursue his own taste on this part of the question, I shall proceet to consider of the best mode of cultivating and cleaning the land for turnips, so as to produce the greatest weight of this valuable root, and at the same time ensure the best possible rotation of crops in successsion. In preparing my land for turnips, notwithstanding the adoption of the method of applying recent lung in drills, by the highest practical authority in this kingdom, Mr. Coke; and the sanction of this practice by the highest chemical authority in this or any other nation, Sir Humphry Davy; I am bold enough to declare, that $\mathrm{I}$ prefer, infinitely profer, that fermented putrescent manure from the dung-heap, which adequate and sufficient fermentation can alone produce from the dung of the barton aud stable-yard; and without which fermentation, the component parts of all furm-yard and stable-dung are crurle, inefficacious, and weak, compared with the effect of ding that has been well fermented, and lain together for a twelvenonth, and then haulded out on the land. Having ventured to differ from these two highest authorities, in so essential a point, as a preference of putrescent to recent dung, it will be incumbent on me to submit my reasons for such difference, to this Honourable Board, by whom, as well as by the great Professor I have named, all facts and arguments submitted to them with hunility and dif- 
fidence, 1 do most humbly and diffidently at this time, will be candidly and condescendingly considered, and fairly weighed and determined.

The reasons which have led me, for upwards of twenty years, to use and prefer putrescent to recent dung, are as follow: I have invariably observed that all dung, exeept the dung of sheep, which falls from animals while grazing, produces little or no benefit to the land; let us add either chopped or long straw to the dung so deposited on the land, and the effeets of both will be small, or nugatory : next collect stable or barton dung in a recent state, and apply it to the land before any fermentation and consequent putrescency have take place; and, in my experience, it has been only a little better than the dung dropped on the land from the aninal: but, ferment and putrefy these very same ingredients, before they are applied to the land, and we obtain one of the most powerful and valuable manuree every discovered; and powerful and valuable in exact proportion to the quality of the food eaten by the animal from whence the dung is obtained, and its consequent putrescency and strength, by which its duration and effect on the land may be practically known.

But it has been said by the highest chemical authority above cited, that the volatile parts, which fly off from a dung-heap during fermentation, are the most valuable and most efficient in promoting vegetation:-I have not practically found this to be the case, hecause my dressings of putrescent dung have invariably produced more luxuriant crops the second, the third, ard sometimes even the fourth year on pasture land, than they have the first ; and if the volatile parts were the most valuable and efficient in promoting vegetation, it should seem this effect could not be produced by putrescent dung-and on arable land a dressing of dung, whether recent or putrescent, renders the land unfit to bear a crop of grain, of any kind, until green crops aud good tilth have amalgamated the dung and the earth, and rendered the land fit for a crop of corn.

I also cunsider it to be the most beneficial mode of applying putrescent dung to the land, to spread it on the surface, and then plongh it in, and afterwards harrow the land, by which much of the dung is brought again to the surface; because, contrary to the opinions of those who suppose the richness of the dung to be exhaled in vapour by the sun, I humbly submit to this Honourable Board, that the effect of a scorching sun, in this climate at least, will be to drive all the moisture of this rich dung downwards into the earth, by which it is absorbed, and not to exhale it in vapour; and by this operation, - which is renewed after every shower and heavy dews which fall on the dung, and so passes into the land,-mose than by any other, I consider soil 
to be improved by the application of dung; and this, by the agency of the sun and air, and rain, upon the dung which is uppermost on the land, is the work of vegetation, in Nature's laboratory; more successfully promoted and carried on, than by any other means. Let the man who doubts this, only observe, as I have often done, the effect of a piece of putrescent dung on the surface, which has happened to be hoed near a potatoe or a turnip when growing, and he will soon be satisfied of the truth of this observation.-For these reasons, and on these principles, without being at all able to state chemically lrow the effects are produced, I prefer using dung in a putrescent to a recent state. I practise spreading it on the surface, and ploughing it in, and then harrowing the ground, instead of burving my dung in the furrow, and there leaving it, that its effects may be spread and felt as universally as possible over the whole surface ; and on these principles, my course of crops are as follows :

As soon as my wheat is cut, I haul out my putrescent dung, say forty to fifty cart-loads to the acre; I plough it in with the stubble, harrow the ground, and sow winter tares;-eat off the tares in April and beginning of May with sheep, and then give the land two. or three earths, as occasion may require, or the season permit, for the turnips;-sow broadeast;-hoe incessantly, so long as weeds will grow; the third hoeing requires very little labour;-eat off my turnips with sheep;-give two ploughings for my barley or oats; - harrow and hand-rake the surface thoroughly after each ploughing, and pick up every weed on the land, which I constantly haul off to a putrescent dungheap preparing for pasture land;-sow clover only with the barley or oats, which remains but one year, and is mown twice for hay:-immediately after the crop is carrjed, break up the clover-ley, run the sheep-fold over the land, and plough thrice for wheat, (never forgetting to harrow well, and pick up and haul off every weed found on each earth, ) which I invariably sow under the furrow; and this completes my course of tillage, which may be repeated to all eternity, while the land will be perpetually in beart, like a horse above his work, and will seldom deceive the industrious cultivator who does not deceive his land; and by this succession I have five crops in four years. I have now pursued this system without variation for years, and I have every reason to prefer it to all others, from the luxuriance of my crops, the cleanliness of my fallows, and the perpetual amelioration of my soil. The farm I now occupy was overwhelmed with couch and colt's-foot at my entrance six years ago, and was incapable of bearing clover; and, in confirmation of this practice, I can only say, that I have repeatedly obtuined from 
fifty bushels to eight quarter's of balley and oats per acre, although at my entrance, when I took to the crops on the ground, $I$ had no more than ten bushels of wheat and fifteen bushels of barley per acre; and last vear I cut thirty-two large waggonloads of clover, at two mowings, from seven acres. I am yet unable to speak of more than twenty-five bushels of whent* per acre, because wheat being my last crop, after the application of $\mathrm{my}$ dung, I have yet had but one crop of wheat from the land since it has been cleaned and manured; and in 1816, every body knows how the wheat crop failed: but in the present, or any future year, I am ready to submit my whole rotation of crops on the ground to the inspection of any person or persons the Board of Agriculture may appoint to examine them; and as the land lies within two miles of Clifton, this may be done with little trouble and wo expense, by any person resorting there, and afterwards submit the produce of them, for quantity and quality, to a comparison with any other crops of the same description, under any other culture than what is similar to my own, in the united kingdom.

I cannot chemically explain to this Honourable Board, why putresent is superior to recent dung, in its use, any more than I can explain, why flour and water, after being mixed, shall by kneading, fermentation, and baking, become most nutritious, powerful, and wholesome food for man, commonly called bread; which it would not be, I presume, if eonsumed or applied to his stomach in the simple shape of four and water;-or why sweetwort shall, by being hopped, boiled, fermented, and stored, become a stronger and better liquor than if drunk while it was a simple infusion of malt and water; and 1 can only appeal to experience for results. But I have always considered those cultivators who have used and recommended recent ding, in preference to putrescent, to be as erroneous and impolitice in their judgements and practice, as those who should contend that simple flour and water, unfermented and unbaked, equals bread; or that an infusion of nualt and water, unfermented and unstored, equals old stingo.

- Sirce this was written, my wheat of 1817 has been thrashed; the produce was exactly $38 \frac{1}{2}$ bushels per acre, wtighing $58 \frac{1}{2} l b$. per bushel.

XXIII. No- 